\title{
HUBUNGAN KEPATUHAN KONSUMSI TTD DENGAN KADAR HEMOGLOBIN PADA REMAJA PUTERI WILAYAH PUSKESMAS BENGKURING TAHUN 2019
}

\author{
Dhito Dwi Pramardika ${ }^{1}$ Fitriana $^{2}$

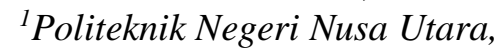 \\ ${ }^{2}$ Akademi Kebidanan Bunga Husada Samarinda \\ Email :dhitodwi@gmail.com, fitriana.pramardika90@gmail.com \\ $\begin{array}{ll}\text { Dikirim } & : 5 \text { September } 2019 \\ \text { Diterima } & : 20 \text { September } 2019 \\ \text { Dipublikasi } & : 28 \text { September } 2019\end{array}$
}

\begin{abstract}
The total consumption of blood added tablets as much as $\geq 52$ tablets carried out for teenage girls in Indonesia is only $1.4 \%$ and the prevalence of anemia in teenage girls is currently at 48.9\% (Riskesdas, 2018). Based on this, this study aims to determine and analyze the relationship of compliance with blood added tablets consumption with hemoglobin $(\mathrm{Hb})$ levels. This research is descriptive research. The one used in this study is a type of correlation research. The sample size in this study is as many as 45 respondents using purposive sampling. The data in this study were processed using Rank Spearman correlation test. There is a significant relationship between the variables of compliance consumption of BAT with Hb levels with a $p$ value of 0.019. With a coefficient value of 0.349 which means moderate and unidirectional, namely increasing compliance consumption of BAT,it will also increase blood hemoglobin (Hb) levels. There is a relationship between Compliance consumption of Iron Suplement (TTD and hemoglobin levels $(H b)$.
\end{abstract}

Keywords: Hemoglobin Levels, Iron Suplement, Teenage girl 
Jurnal Kebidanan Mutiara Mahakam, Vol 7 , No 2, Tahun 2019, Hal 58-66

\section{PENDAHULUAN}

Berdasarkan data World Health Organization (WHO) tahun 2014, bahwa angka kejadian anemia defisiensi besi di benua Asia yaitu $>75 \%$. Kejadian anemia ini banyak dialami pada remaja dan ibu hamil. Berdasarkan WHO tahun 2013, angka kejadian anemia di dunia cukup tinggi pada remaja putri yaitu sebesar $26,2 \%$ dan angka kejadian pada perempuan yaitu sebesar 49,1\% (Kemenkes RI, 2013).

Anemia saat ini merupakan masalah gizi di negara berkembang termasuk Indonesia. Angka kejadian anemia remaja saat ini adalah sebanyak 48,9\% sementara jumlah konsumsi tablet tambah darah $<52$ butir sebesar 98,6\% dan yang mengkonsumsi $\geq 52$ butir sebesar 1,4\% (Riskesdas, 2018). Rendahnya kepatuhan dan meningkatnya anemia pada remaja merupakan permasalahan yang perlu segera untuk ditangani, mengingat remaja puteri merupakan seorang calon ibu yang kelak akan hamil dan menghasilkan keturunan dari sebuah generasi, sehingga apabila tidak ditangani maka akan memperbesar risiko kematian ibu melahirkan, bayi lahir prematur dan berat bayi lahir rendah (BBLR) (Dieny, 2014).

Remaja putri diwajibkan untuk minum Tablet Tambah Darah (TTD) dikarenakan mereka mengalami siklus menstruasi yang datang setiap bulannya. TTD ini sangat bermanfaat dalam meregenerasi zat besi yang telah hilang dikarenakan menstruasi serta untuk memenuhi kebutuhan Fe yang belum terpenuhi dari makanan. TTD pada remaja putri juga berguna dalam menambah konsentrasi dalam hal belajar, menjaga kebugaran serta sebagai preventif terjadinya anemia pada calon ibu hamil di masa datang (Dieny, 2014).

Berdasarkan Depkes aturan kepatuhan minum TTD sebagai tindakan pencegahan atau preventif adalah sebanyak satu tablet setiap minggu. Kepatuhan remaja puteri minum TTD merupakan faktor penting dalam menjamin peningkatan kadar hemoglobin pada remaja. Batas kadar $\mathrm{Hb}$ remaja putri untuk mendiagnosis anemia yaitu apabila kadar $\mathrm{Hb}$ kurang dari $12 \mathrm{gr} / \mathrm{dl}$

Puskesmas Bengkuring merupakan salah satu dari 24 Puskesmas yang berada di wilayah kota Samarinda. Program ini sudah berjalan sejak tahun 2018, hingga saat ini. TTD ini dibagikan pada 9 SMP dan 8 SMA yaitu sebanyak 1.799 siswi (Penjamas UPT Puskesmas Bengkuring, 2018).

Berdasarkan hal tersebut, tujuan dari peneliti ini adalah untuk mengetahui dan menganalisis hubungan kepatuhan konsumsi TTD dengan kadar hemoglobin (Hb) pada remaja puteri di wilayah kerja UPT Puskesmas Bengkuring Kota Samarinda tahun 2019. 


\section{METODE PENELITIAN}

Penelitian ini dilaksanakan pada tanggal 1 April 2019 sampai dengan 31 Mei 2019. Penelitian ini merupakan descriptive research yaitu penelitian korelasi.

Penelitian ini melakukan pemeriksaan kadar Hemoglobin $(\mathrm{Hb})$ darah pada remaja Puteri dengan menggunakan alat HB digital dengan merk Easy Touch kepada 45 remaja puteri dari 2 kelurahan di wilayah kerja Puskesmas Bengkuring yaitu SMKN 16 Kelurahan Sempaja Timur dan SMKN Pelayaran Kelurahan Sempaja Utara. Sementara data tingkat kepatuhan diperoleh berdasarkan hasil wawancara dengan menggunakan kuesioner.

Pengambilan sampel pada penelitian ini adalah dengan menggunakan purpossive sampling, yang kemudian data tersebut akan dianalisis dan diolah dengan menggunakan uji korelasi Rank Spearman dengan bantuan program aplikasi SPSS.

\section{HASIL DAN [EMBAHASAN}

\section{A. HASIL}

\section{Karakteristik Responden}

a) Usia

Berdasarkan data yang diperoleh menurut karakteristik responden berdasarkan usianya adalah sebagai berikut :

\begin{tabular}{ccc}
\multicolumn{3}{c}{ Tabel 1. Karakteristik Responden berdasarkan Usia } \\
\hline Usia & Frekuensi & Persentase (\%) \\
\hline Remaja Awal & 26 & 57,8 \\
Remaja Akhir & 19 & 42,2 \\
Total & 45 & 100
\end{tabular}

Berdasarkan tabel 1 diketahui bahwa pembagian usia pada penelitian ini berdasarkan depkes yaitu remaja awal (usia 12-16 tahun) sebesar 57,8\% dari total 45 responden. Sedangkan responden yang termasuk dalam usia remaja akhir (17-25 tahun) adalah sebesar $42,2 \%$ dari total 45 responden.

\section{Hasil Univariat}

a) Menstruasi

Berdasarkan data yang diperoleh diketahui distribusi frekuensi menurut Menstruasi adalah sebagai berikut :

Tabel 2. Distribusi Frekuensi Responden Berdasarkan Menstruasi

\begin{tabular}{ccc}
\hline Menstruasi & Frekuensi & Persentase (\%) \\
\hline Sedang Menstruasi & 7 & 15,6 \\
Tidak sedang Menstruasi & 38 & 84,4 \\
Total & 45 & 100 \\
\hline
\end{tabular}


Berdasarkan tabel 2 diketahui bahwa pada penelitian ini yang sedang mengalami menstruasi sebesar $15,6 \%$ dari total 45 responden. Sedangkan responden yang tidak sedang menstruasi saat penelitian adalah sebesar $84,4 \%$ dari total 45 responden.

b) Kepatuhan Konsumsi TTD

Berdasarkan data yang diperoleh diketahui bahwa distribusi frekuensi responden berdasarkan kepatuhan konsumsi TTD adalah sebagai berikut :

Tabel 3 Distribusi Frekuensi Responden berdasarkan Kepatuhan Konsumsi TTD

\begin{tabular}{ccc}
\hline $\begin{array}{c}\text { Kepatuhan } \\
\text { TTD }\end{array}$ & Frekuensi & $\begin{array}{c}\text { Persentase } \\
(\%)\end{array}$ \\
\hline Patuh & 43 & 95,6 \\
Tidak Patuh & 2 & 4,4 \\
Total & 45 & 100 \\
\hline
\end{tabular}

Berdasarkan tabel 3 diketahui bahwa pada penelitian ini yang patuh mengkonsumsi Tablet Tambah Darah (TTD) sebesar 95,6\% dari total 45 responden. Sedangkan responden yang tidak patuh dalam mengkonsumsi TTD adalah sebesar 4,4\% dari total 45 responden.

c) Kadar Hemoglobin Darah (Hb)

Berdasarkan data yang diperoleh diketahui bahwa distribusi frekuensi berdasarkan kadar hemoglobin darah adalah sebagai berikut:

Tabel 4 Distribusi Frekuensi Responden berdasarkan Kadar Hemoglobin Darah

\begin{tabular}{ccc}
\hline Kadar $\mathrm{Hb}$ & Frekuensi & Persentase $(\%)$ \\
& & \\
\hline$<12$ gr/dl & 13 & 28,9 \\
$\geq 12$ gr/dl & 32 & 71,1 \\
Total & 45 & 100 \\
\hline Berdasarkan tabel 4 & diketahui bahwa pada penelitian ini yang
\end{tabular}
mengalami anemia adalah sebesar 28,9\% dari total 45 responden. Sedangkan responden yang tidak mengalami anemia adalah sebesar $71,1 \%$ dari total 45 responden. 


\section{Hasil Bivariat}

a) Hubungan Kepatuhan Konsumsi TTD Dengan Kadar HB

Untuk melihat pengaruh kepatuhan konsumsi TTD dengan kejadian anemia pada remaja puteri di wilayah kerja Puskesmas Bengkuring Kota Samarinda diperoleh data sebagai berikut :

Tabel 5 Hubungan Kepatuhan Konsumsi TTD Dengan Kejadian Anemia

\begin{tabular}{|c|c|c|c|c|}
\hline \multirow{7}{*}{  } & \multirow{4}{*}{$\begin{array}{l}\text { kepatuhan } \\
\text { minum } \\
\text { TTD }\end{array}$} & \multirow{4}{*}{$\begin{array}{c}\text { Correlation } \\
\text { Coefficient } \\
\text { Sig. (2-tailed) } \\
\mathrm{N} \\
\end{array}$} & \multicolumn{2}{|c|}{ Kepatuhan|Kadar } \\
\hline & & & & $\mathrm{Hb}$ \\
\hline & & & 1,000 &, $349^{*}$ \\
\hline & & & i5 &, 019 \\
\hline & \multirow{4}{*}{ kadar $\mathrm{Hb}$} & Correlation & & \\
\hline & & Coefficient & & 1,000 \\
\hline & & Sig. (2-tailed) & ,019 & \\
\hline & & $\mathrm{N}$ & 45 & 45 \\
\hline
\end{tabular}

Berdasarkan tabel 5 diketahui bahwa pada penelitian ini diperoleh angka koefisien sebesar 0,349. Artinya, tingkat kekuatan hubungan antara variabel kepatuhan konsumsi Tablet Tambah Darah (TTD) dengan kadar hemoglobin ( $\mathrm{Hb}$ ) adalah sebesar 0,349 atau hubungan moderat berdasarkan tabel intepretasi menurut D.A. de Vaus pada angka signifikansi sebesar 0,05 .

Angka koefisien korelasi pada hasil diatas, bernilai positif, yaitu 0,349, sehingga hubungan kedua variabel tersebut bersifat searah, dengan demikian dapat diartikan bahwa semakin ditingkatkan kepatuhan konsumsi TTD pada remaja puteri di wilayah kerja Puskesmas Bengkuring Kota Samarinda maka kadar Hemoglobin $(\mathrm{Hb})$ darah juga akan meningkat.

Berdasarkan tabel 5, diketahui nilai signifikansi atau sig. (2tailed) sebesar 0,019, karena nilai. (2-tailed) 0,019 < lebih kecil dari 0,05 maka artinya ada hubungan yang signifikan (berarti) antara variabel kepatuhan konusmsi TTD dengan Kadar $\mathrm{Hb}$ pada remaja puteri di wilayah kerja UPT Puskesmas Bengkuring Kota Samarinda Tahun 2019. 


\section{B. PEMbahasan}

Berdasarkan hasil penelitian yang telah dilakukan diketahui bahwa kepatuhan konsumsi Tablet Tambah Darah (TTD) berhubungan dengan kadar hemoglobin $(\mathrm{Hb})$. Hal itu sejalan dengan penelitian yang dilakukan Permatasari (2018) yang menyatakan bahwa selama 4 bulan intervensi yang dilakukan dengan pemberian suplementasi besi dari 20,7\% angka kejadian anemia menurun menjadi 15,2\% dari 172 responden. Dan penelitian yang sama juga pernah dilakukan oleh Casey tahun 2009 di negara Vietnam yang dilakukan pada wanita usia subur selama 3 bulan intervensi yaitu terjadi peningkatan kadar $\mathrm{Hb}$ yakni rata-rata sebesar $9.6 \mathrm{~g} / \mathrm{dl}$.

Program pemberian Tablet Tambah Darah (TTD) yang dilakukan oleh Puskesmas Bengkuring cukup baik. Hal ini terlihat dari hasil pengukuran kadar Hemoglobin < 12 gr/dl sebesar 28,9\% dari total 45 responden. Hal itu dikarenakan program ini telah berjalan kurang lebih 1 tahun lebih. Hal ini terlihat dari angka kepatuhan konsumsi TTD sebesar 95,6\% dari 45 responden.

Tingginya angka kepatuhan konsumsi TTD tersebut disebabkan oleh peran dari petugas puskesmas dan peran serta dari guru UKS yang ikut dalam memberikan penyuluhan mengenai TTD tersebut. Hal itu sesuai Notoatmodjo (2012) yang menyatakan bahwa Informasi yang diperoleh dapat memberikan landasan kognitif. Kemudian faktor situasional yang mencakup lingkungan di mana manusia itu bertempat tinggal, baik itu lingkungan fisik, sosial, budaya, ekonomi, politik dan sebagainya dapat mempengaruhi perilaku seseorang. Pengetahuan atau kognitif merupakan domain yang sangat penting dalam membentuk tindakan seseorang (over behaviour) karena dari pengalaman penelitian terbukti bahwa perihal yang didasari oleh pengetahuan lebih langgeng daripada perilaku yang tidak didasari oleh pengetahuan

Berdasarkan hasil wawancara juga didaptkan bahwa kepatuhan konsumsi TTD ini juga dikarenakan Dinas Kesehatan Kota Samarinda melakukan penggantian jenis TTD dari tahun 2018 tablet tambah darah yang berasal dari kimia Farma menjadi hemafort dari phapros pada tahun 2019 ini. Ternyata penggantian TTD ini lebih disukai remaja puteri karena rasanya yang manis.

Meskipun masih terdapat angka kejadian anemia sebesar 28,9\% dari 45 responden. Hal itu dikarenakan dari 15,6 responden yang sedang mengalami 
periode menstruasi dan tidak mengkonsumsi TTD sebesar 4,4\% yang mempengaruhi kadar hemoglobin di dalam darah.

Hal ini sejalan dengan penelitian Fitriana (2017) yang menyatakan bahwa 6 dari 10 remaja puteri mengalami anemia dan semakin panjang dari pola menstruasi maka 24,23 kali mengalami anemia dibandingkan dengan pola menstruasi pendek. Selain itu juga dikarenakan kurangnya penyerapan zat besi diakibatkan kurangnya pengetahuan terhadap makanan yang kaya akan zat besi dan makanan yang dapat menghambat penyerapan zat besi.

Penyerapan zat besi dipengaruhi oleh 2 faktor. Faktor pendorong (enhancer) dan penghambat (inhibitor) menjadi perhatian penting dalam menilai asupan zat besi. Terdapat beberapa zat gizi mikro yang digunakan bersama-sama dengan zat besi untuk meningkatkan penyerapan zat gizi yang disebut dengan faktor pendorong diantaranya vitamin A, vitamin $\mathrm{C}$, vitamin $\mathrm{B} 2$, dan vitamin B67. Namun, terdapat juga beberapa zat dalam makanan yang dapat menjadi penghambat penyerapan zat besi atau inhibitor. Zat tannin dalam teh dan kopi termasuk inhibitor kuat bagi zat besi. Selain itu pada makanan yang mengandung kalsium, fosfat, maupun fitat yang dikonsumsi dalam jumlah besar akan mengganggu penyerapan dari zat besi tersebut

\section{SIMPULAN}

Berdasarkan hasil penelitian didapatkan kesimpulan bahwa kepatuhan konsumsi Tablet Tambah Darah (TTD) berhubungan dengan kadar hemoglobin (Hb)

\section{SARAN}

1. Bagi Pelayanan Kesehatan

Penelitian ini diharapkan dapat dijadikan masukan terhadap program pemberian Tablet Tambah Darah (TTD) seperti peningkatan penyuluhan kesehatan tidak hanya pada remaja puteri namun juga dilakukan pada guru sekolah mengenai faktor enhancer dan faktor inhibitor serta pemeriksaan hemoglobin $(\mathrm{Hb})$ darah rutin dilakukan 2 kali dalam setahun.

2. Bagi Institusi Pendidikan

Penelitian ini sebagai evaluasi pada pelaksanaan program kesehatan di institusi pendidikan yaitu ikut melakukan edukasi dan pengawasan terhadap kepatuhan dalam konsumsi TTD serta asupan makanan pada siswi di sekolahnya. 
Jurnal Kebidanan Mutiara Mahakam, Vol 7 , No 2, Tahun 2019, Hal 58-66

3. Bagi peneliti selanjutnya

Penelitian ini dapat digunakan sebagai referensi dan dapat dikembangkan lagi misalnya penelitian mengenai faktor asupan enhancer dan inhbitor terhadap kadar hemoglobin darah pada remaja puteri.

\section{DAFTAR PUSTAKA}

Casey GJ, Phuc TQ, MacGregor L, Montresor A, Mihrshahi S, Thach TD, Nong Tien, Biggs Beverley-Ann, (2009). A Free Weekly Iron-Folic Acid Supplementation and Regular Deworming Program is Associated with Improved Hemoglobin and Iron Status Indica Tors in Vietnamese Women. BMC Public Health.; 9:261

D.A. de Vaus (2002), Survey in Social Research, 5th Edition (New South Wales: Allen and Unwin) p. 259

Dieny, F. (2014). Permasalahan Gizi pada Remaja Putri. Graha Ilmu. Yogyakarta

Fitriana. (2017). Pola Menstruasi Dengan Kejadian Anemia Remaja Di Akbid Bunga Husada Samarinda Tahun 2017. Mahakam Midwifery Journal. Vol 2, No. 1, Mei $2017: 23-32$

Hallberg, B. Sandstrom and P.J. Agget L. Iron, zinc and other trace elements. (1994). In : Human Nutrition and Dietetics. Churchill Livingstone.

Kemenkes RI. (2016) . Pedoman Pencegahan dan Penanggulangan Anemia Pada Remaja Putri dan Wanita Usia Subur (WUS). Ditjen Kesehatan Masyarakat Bina Gizi Masyarakat.

Kementerian Kesehatan Indonesia. (2015). Rencana Strategis Kementerian Kesehatan Tahun 2015-2019. Jakarta : Kementerian Kesehatan Indonesia

Kementerian Kesehatan Indonesia. (2018).Hasil utama Riset Kesehatan Dasar. Kementerian kesehatan republik Indonesia. Badan penelitian dan pengembangan. Jakarta

Kementerian Kesehatan Indonesia. Kenali Masalah Gizi yanng Mengancam Remaja Indonesia. Biro Komunikasi dan Pelayanan Masyarakat, Kementerian Kesehatan RI. Tersedia di : http://www.depkes.go.id/pdf.php?id=180516 00005 (diakses 11 Juni 2019)

Kementerian Kesehatan Indonesia. Pesan Untuk Remaja Putri Indonesia: Cantik Itu Sehat, Bukan Kurus. Biro Komunikasi dan Pelayanan Masyarakat, Kementerian Kesehatan RI. Tersedia di : http://www.depkes.go.id/article/view/181123 00003/pesan-untuk-remaja-putri-indonesia-cantik-itu-sehat-bukan-kurus.html (diakses 11 Juni 2019)

Notoatmodjo, S., (2012). Promosi Kesehatan dan Ilmu Perilaku, Rineka Cipta, Jakarta. 
Jurnal Kebidanan Mutiara Mahakam, Vol 7 , No 2, Tahun 2019, Hal 58-66

Permatasari, Tyas \& Briawan, Dodik \& Madanijah, Siti. (2018). Efektifitas Program Suplementasi Zat Besi pada Remaja Putri di Kota Bogor. Media Kesehatan Masyarakat Indonesia. 14. 1. 10.30597/mkmi.v14i1.3705

Puskesmas Bengkuring. (2018). Penilaian Kinerja Puskesmas (Penjamas) UPT Puskesmas Bengkuring Kota Samarinda provinsi Kalimantan Timur Tahun 2018.

Sizer, F. S. \& Whitney, E. (2013). Nutrition: Concept and Controversies. (Brooks Cole)

Sugiyono. (2013). Metode Penelitian Manajemen : Pendekatan, Kauntitatif, Kualitatif, Kombinasi (Mixed Methods), Penelitian Tindakan (Action Research), Penelitian Evaluasi.Bandung. Alfabeta 